\title{
ESTIMATION OF SOME GENETICAL PARAMETERS AND THEIR IMPLICATION ON YIELD IMPROVEMENT IN MAIZE USING TWO SELECTION METHODS

\author{
El-Seidy, E. H. ${ }^{*}$; A. M. Shehata** and R. H. A. Alsebaey ${ }^{\star *}$ \\ * Dep. of Agron., Fac. Agri., Tanta Unv. \\ ** Maize Res. Dep., Field Crops Res. Inst., Agric. Res. Center, Cairo, \\ Egypt.
}

\begin{abstract}
Prediction is of great importance for the reasoning on the feasibility of completion the selection process. In this study, we compared the expected effectiveness of two intrapopulation selection methods of $S_{1}$ progeny and half-sib progeny via Design I mating scheme in improving the yield of Nubaria yellow maize population (NYP). For fairer comparison, we unified germplasm used in the two methods by using $S_{1}$ seeds supposed to be kept for recombination in half-sib family selection as a germplasm of $S_{1}$ family selection. This permitted studying the outbred and inbred progeny for the same parent. Our germplasm involved $81 \mathrm{~S}_{1}$ families, and 324 full-sib families forming 81 half-sib families. Evaluation were done at Gemmeiza and Sids locations representing two different environments of Middle Delta and Upper Egypt regions, respectively. By looking over the performance of couples of families for parents, there was no clear relation between performance of inbred and outbred families. Design I analysis showed predominance of additive genetic variance component in all studied traits in both environments, whereas dominance variance had negative values in most cases. Influence of environment was obvious on changing genetic variance from location to another. Heritability values were high for both progenies for most studied traits at both locations. Genetic gains were conflicting among different studied traits. The preference was for $S_{1}$ family selection for yield components (ear diameter, ear length and kernels number/ear), except rows number/ ear where the advantage was for half-sib family selection adding to plant height, ear height and ear position traits. Both methods were almost equal for $50 \%$ silking and still $S_{1}$ family selection has the bigger expected gain for grain yield trait.
\end{abstract}

\section{INTRODUCTION}

It is of great importance to have information about genetic parameters in populations in order to assign the proper method of selection that achieves maximum amount of improvement in performance. By knowing information about genetic variance components, we could determine expected genetic gain through estimating the heritability, where its high values are considered a good indicator to effectiveness of the selection process. Genetic estimates varied for each population, sample, method and environment. Rationally, additive genetic variance measured from $S_{1}$ progeny selection is overestimated. Many researchers have used North Calorina designs for more logical estimates for genetic variance components; e.g., Hallauer and Miranda (1981) summarized the estimates of additive variance $\left(\boldsymbol{\sigma}^{2} \mathbf{A}\right)$ and dominance variance $\left(\boldsymbol{\sigma}^{2} \mathbf{D}\right)$ from many studies and came to the 
conclusion of assuming no epistasis and linkage effects, $\boldsymbol{\sigma}^{2} \mathbf{A}$ on the average accounted for $61.2 \%$ and $\boldsymbol{\sigma}^{2} \mathbf{D}$ accounted for $38.8 \%$ of the total genetic variation for yield. This implies to the important role that could be played by selection in improving maize populations.

In this study we used procedures of two intrapopulation selection methods; i.e., $S_{1}$ progeny and half-sib family via Design I scheme as introduced by Comstock and Robinson (1948) aiming to:

- assessing genetic variance components and heritability for traits of interest

- comparing between expected genetic gains for both selection methods.

\section{MATERIALS AND METHODES}

\section{Germplasm}

The source of germplasm under this study (NYP) was composed at Nubaria Agricultural Research Station, Maize Department by intermating 4 local and 10 exotic sources of : ADA._Pop. (Turkey), Arify Pop. (Turkey), AE. Pop. (Turkey), Pop.21 (CIM.), Pop.24 (CIM.), Wistigua Pop. (CIM.), Pop.33 (CIM.), Pop.34 (CIM.), Pop.44 (CIM.), S.C. $155-F_{2}$, S.C. $162-F_{2}$, T.W.C. $351-F_{2}$, T.W.C. $352-F_{2}$ and inbred B.73 (USA).

\section{Forming of germplasm}

The progenies required for half-sib family selection via Design I mating scheme as introduced by Comstock and Robinson (1948) and for $S_{1}$ family selection were produced in maize crossing field at Gemmeiza Agricultural Research Station in 2009 season. Approximately 150 random So plants of N.Y.P. were selfed and at the same time each were mated to 4 random female plants. Successful pollinations with sufficient seeds were selected, to remain with us 81 parents $\left(\mathrm{S}_{0}\right)$ group, each one consisting of one $S_{1}$ family (the selfed ear) and one half-sib family (forming from four full-sib families, i.e., each ear of female represents full-sib family) that have one parent in common. It is worth mentioning that we used $S_{1}$ seeds supposed to be kept for recombination in half-sib family selection method as a germplasm of $S_{1}$ family selection method to unify germplasm used in the two methods in order to make fairer comparison between them. This also permitted studying the outbred and inbred progeny of the parents.

Evaluating of germplasm : The formed progenies representing in $81 \mathrm{~S}_{1}$ families and 324 full-sib families forming 81 half-sib families for 81 males were under evaluation as a selection unit at Gemmeiza and Sids Agricultural Research Stations in 2010 season. Two progeny evaluation trials were carried out for evaluating $S_{1}$ families and full- and half-sib families. Both trials were arranged in simple lattice design as outlined by Cochran and Cox (1957) $(9 \times 9)$ with two replications, one row for plot in the first trial and 4 rows of full sibs for plot in the second trial, row was $4 \mathrm{~m}$ in length with $0.8 \mathrm{~m}$ between rows and $0.25 \mathrm{~m}$ spaces between hills within the row. Hills were thinned to one plant per hill before the first irrigation. All normal agricultural 
practices for maize production were applied as recommended in both trials at the proper time.

Data was recorded on the following characters: days to $50 \%$ silking, plant height, ear height, ear position, ear length, ear diameter, No. of rows/ear, No. of kernels/row, and grain yield.

Data analysis: The efficiency of using analysis of variance for Lattice design compared with Randomized Complete Block analysis was not of great importance; the adjustment factor $(\mu)$ in some cases was approximately zero where the intra block M.S (Ee) > block adjusted M.S (Eb). Therefore, the data of half- and full-sib families were amenable to analyze in sets with Design I analysis of variance to provide information about components of genetic variance for the traits of interest in our population. The analysis contained 9 sets, each involved 9 males; i.e., 36 full-sibs for one set. What is on view for a single location, whereas there was no homogeneity between errors variance of the two locations. Also, for $S_{1}$ progeny trial, we could depending on the analysis of RCBD.

Inbreeding depression calculated as mean performance of the outbred mean performance of $S_{1}$

Phenotypic and genotypic variances were used in both trials analysis to estimate each of :

Heritability in narrow sense $\left(h^{2}\right)$ :

For $S_{1}$ progeny trial $=\delta^{2} \mathrm{G} / \delta^{2} \mathrm{Ph}$ (where $\delta^{2} \mathrm{G}=\delta^{2} \mathrm{~A}$ additive genetic action according to Empig, et al (1972)).

For full- and half-sib progeny trial $=\delta^{2} \mathrm{~A} / \delta^{2} \mathrm{Ph}$

Expected genetic gain $=\mathrm{k} \times \mathrm{h}^{2} \times \delta \mathrm{Ph}$ according to Falconer (1960).

Where $: \mathrm{k}=\mathrm{a}$ value depends on selection intensity, it equals 1.76 at selection intensities $10 \% \& \delta \mathrm{Ph}=$ phenotypic standard deviation.

\section{RESULTS AND DISSCUSSION}

Mean and range of performance for both $S_{1}$ and full-sib progenies is shown in Table (1) which exhibited the following : genetic materials either $S_{1}$ or full sib was earlier and taller at Sids location influenced by its circumstances whence shorter day and more favorable environment. Despite ear height for both $S_{1}$ and full-sib families was lower at Gemmeiza location, but ear position percentage was lower at Sids location. For studied yield components, Sids location had the larger values of mean performance for both $S_{1}$ and full-sib families. However for grain yield, there was observed reduction in mean performance of full-sibs at Gemmeiza location than at Sids location, meanwhile both locations apparently did not differ in the mean performance of $S_{1}$ families. It is evident that Gemmeiza location had less favorable circumstances than Sids location. Results of Gamea (2010) pointed to the same result. May be this result due to high level of soil water at this location.

Ranges of performance for most studied traits for both $\mathrm{S}_{1}$ and full-sib families broaden at Gemmeiza than at Sids location, indicating more variability occurred under this location circumstances. Minimum ranges were obtained at Gemmeiza location, while maximum values were at Sids location 
for most traits; reflected case happened for days to $50 \%$ silking where earliness was in favor of Sids location as mentioned before. This is asserting that Gemmeiza location had less favorable circumstances than at sids location.

Any way, poor performance was notable for $S_{1}$ families and barrenness was occurred in some $S_{1}$ rows. This clarified more with average of inbreeding depression occurred in the first self-generation shown in Table 2.

Table 1 : Mean and range of performance for $S_{1}$ and full-sib progenies at Gemmeiza and Sids locations for all studied traits.

\begin{tabular}{|c|c|c|c|c|c|}
\hline \multirow{2}{*}{ Traits } & \multirow{2}{*}{ Perfor. } & \multicolumn{2}{|c|}{ Inbred $\left(\mathbf{S}_{1}\right)$} & \multicolumn{2}{|c|}{ Outbred (F.S) } \\
\hline & & Gem. & Sids & Gem. & Sids \\
\hline \multirow{2}{*}{$\begin{array}{l}\text { Days to } 50 \% \\
\text { silking }\end{array}$} & Range & $58-70$ & $57-65$ & $56-68$ & $55-65$ \\
\hline & Mean & 64 & 61 & 60 & 58 \\
\hline \multirow{2}{*}{$\begin{array}{l}\text { Plant height } \\
(\mathrm{Cm})\end{array}$} & Range & $123-232$ & $180-276$ & $172-285$ & $195-275$ \\
\hline & Mean & 176 & 221 & 233 & 242 \\
\hline \multirow{2}{*}{$\begin{array}{l}\text { Ear Height } \\
(\mathrm{Cm})\end{array}$} & Range & $75-135$ & $96-142$ & $87-179$ & $100-165$ \\
\hline & Mean & 99 & 119 & 131 & 134 \\
\hline \multirow{2}{*}{$\begin{array}{l}\text { Ear position } \\
\%)(\end{array}$} & Range & $46-65$ & $47-59$ & $40-68$ & $47-64$ \\
\hline & Mean & 57 & 54.1 & 56.4 & 55.4 \\
\hline \multirow{2}{*}{$\begin{array}{l}\text { Ear length } \\
(\mathrm{Cm})\end{array}$} & Range & $10-19$ & $13-22$ & $9-22$ & $9-24$ \\
\hline & Mean & 14.6 & 17.9 & 17.3 & 19.4 \\
\hline \multirow{2}{*}{$\begin{array}{l}\text { Ear diameter } \\
(\mathrm{Cm})\end{array}$} & Range & $3-4.8$ & $3.8-4.9$ & $2-5$ & $2.6-5.8$ \\
\hline & Mean & 3.9 & 4.3 & 4.1 & 4.6 \\
\hline \multirow{2}{*}{$\begin{array}{l}\text { Rows } \\
\text { number/ear }\end{array}$} & Range & $11.3-17.4$ & $13.4-18.3$ & $11.3-20.8$ & $11.6-19.6$ \\
\hline & Mean & 14.3 & 15.6 & 15.1 & 15.4 \\
\hline \multirow{2}{*}{$\begin{array}{l}\text { Kernels } \\
\text { number/row }\end{array}$} & Range & $18-40$ & $31-46$ & $26-48$ & $29-50$ \\
\hline & Mean & 30 & 40 & 38 & 41 \\
\hline \multirow{2}{*}{$\begin{array}{l}\text { Grain yield } \\
\text { (ard/fad) }\end{array}$} & Range & $1.47-25.82$ & $2.63-29.11$ & $3.49-29.21$ & $11.13-36.22$ \\
\hline & Mean & 9.140 & 8.870 & 18.730 & 26.490 \\
\hline
\end{tabular}

Inbreeding depression occurred in the first self-generation : Depending on the average of inbreeding depression shown in Table 2, distinctly, yield ranked the first among all the studied traits affecting with inbreeding depression, followed by ear height, plant height, kernels number/ear, ear length, ear diameter, days to $50 \%$ silking, rows number/ear and finally ear position with an average percentage of reduction than the outbred family performance over the two locations $60,18,17,13,12,7,-6,2$ and $0.5 \%$, respectively. Depression in our results was great, may this could be interpreted by what Hallauer and Miranda (1981) mentioned about "the initiation of selfing in recently hybridized exotic-adapted germplasm usually has been disastrous; inbreeding depression is severe and few vigorous lines were obtained". In all studied traits, range of inbreeding depression broadened at Gemmeiza location; that can be explained as a result of enlarge of variation showed in the previous results under this location circumstances. Also, Gemmeiza location had the higher values and percentages of inbreeding depression for most traits; that can be explained by the fact that the more favorable circumstances of Sids location led to reduce the difference in performance between the inbred and the outbred under this location than Gemmeiza location in most studied traits. 
J. Plant Production, Mansoura Univ., Vol. 4 (8), August, 2013

Table 2 : Inbreeding depression occurred in the first self-generation for all the studied traits at both locations.

\begin{tabular}{|c|c|c|c|c|c|c|c|c|}
\hline \multirow{3}{*}{ Traits } & \multirow{3}{*}{ locations } & \multicolumn{6}{|c|}{ Inbreeding depression } & \multirow{3}{*}{$\begin{array}{c}\text { Average } \\
\text { over the } \\
\text { two loc. } \\
(\%)\end{array}$} \\
\hline & & \multicolumn{2}{|c|}{$\begin{array}{c}\text { Rang for } \\
\left(\text { Full sib }-S_{1}\right)\end{array}$} & \multicolumn{2}{|c|}{$\begin{array}{c}\text { Rang for } \\
\text { (half. sib }-S_{1} \text { ) }\end{array}$} & \multicolumn{2}{|c|}{$\begin{array}{c}\text { general } \\
\text { Mean }\end{array}$} & \\
\hline & & $\begin{array}{c}\text { As } \\
\text { Value }\end{array}$ & $\begin{array}{l}\text { As } \\
(\%)\end{array}$ & $\begin{array}{c}\text { As } \\
\text { Value }\end{array}$ & $\begin{array}{l}\text { As } \\
(\%)\end{array}$ & $\begin{array}{c}\text { As } \\
\text { value }\end{array}$ & $\begin{array}{l}\text { As } \\
(\%)\end{array}$ & \\
\hline \multirow[t]{4}{*}{$\begin{array}{l}\text { Days to } 50 \% \\
\text { silking }\end{array}$} & Gem. & -10 & -17 & -9 & -14 & -4 & -6 & \multirow{4}{*}{$7-$} \\
\hline & & 3 & 0 & 2 & 4 & & & \\
\hline & Sids & -10 & -12 & -6 & -11 & -3 & -6 & \\
\hline & & 3 & 4 & 1 & 2 & & & \\
\hline \multirow{4}{*}{$\begin{array}{l}\text { Plant } \\
\text { (cm) }\end{array}$} & Gem. & -40 & -23 & 0 & 0 & 57 & 24 & \multirow{4}{*}{ iv } \\
\hline & & $11 \mathrm{~V}$ & 47 & 107 & 45 & & & \\
\hline & & -40 & -10 & -9 & -4 & & & \\
\hline & Sids & 65 & 27 & 51 & 22 & 22 & 9 & \\
\hline \multirow{4}{*}{$\begin{array}{l}\text { Ear } \\
(\mathrm{cm})\end{array}$} & & -33 & -33 & -10 & -8 & & & \multirow{4}{*}{11} \\
\hline & Gem. & & & 64 & 46 & 32 & $r \varepsilon$ & \\
\hline & & -33 & -20 & -8 & -6 & & & \\
\hline & Sids & & 28 & 31 & 23 & 15 & 11 & \\
\hline \multirow{5}{*}{$\begin{array}{l}\text { Ear } \\
(\%)\end{array}$} & & -12 & -24 & -8 & -15 & \multirow[b]{2}{*}{-0.6} & \multirow[b]{2}{*}{-1} & \multirow{5}{*}{., 0} \\
\hline & Gem. & 10 & 17 & 9 & 15 & & & \\
\hline & & -12 & -16 & -4 & -7 & & & \\
\hline & Sids & & & & & 1.3 & 2 & \\
\hline & & 7 & 12 & 5.6 & 10 & & & \\
\hline \multirow{4}{*}{$\begin{array}{l}\text { Ear } \\
(\mathrm{cm})\end{array}$} & & -10 & -102 & -4 & -29 & & & \multirow{4}{*}{12} \\
\hline & Gem. & 10 & 48 & 8 & 42 & 2.7 & 16 & \\
\hline & & -10 & -52 & -3 & -15 & & & \\
\hline & Sids & 7 & 34 & 6 & 32 & 1.5 & 8 & \\
\hline \multirow{4}{*}{$\begin{array}{l}\text { Ear } \\
(\mathrm{cm})\end{array}$} & & -2.6 & -130 & -0.9 & -23 & & & \multirow{4}{*}{ v } \\
\hline & Gem. & 17 & 35 & 13 & 30 & 0.2 & 6 & \\
\hline & & -2.6 & $\frac{35}{-26}$ & $\frac{1.3}{-0.2}$ & $\frac{30}{-5}$ & & & \\
\hline & Sids & 1.1 & 22 & 0.9 & 18 & 0.3 & 7 & \\
\hline
\end{tabular}


El-Seidy, E. H. et al.

Count of Table 2

\begin{tabular}{|c|c|c|c|c|c|c|c|c|}
\hline \multirow{2}{*}{$\begin{array}{l}\text { Rows } \\
\text { number/ear }\end{array}$} & Gem. & $\begin{array}{c}-3.1 \\
6.4\end{array}$ & $\begin{array}{r}-25 \\
35\end{array}$ & $\begin{array}{c}-1.5 \\
4.7\end{array}$ & $\begin{array}{r}-10 \\
28\end{array}$ & $\cdot, \wedge$ & 0 & \multirow[t]{2}{*}{ r } \\
\hline & Sids & $\begin{array}{c}-3.1 \\
3.2\end{array}$ & $\begin{array}{r}-21 \\
19\end{array}$ & $\begin{array}{c}-2.3 \\
1.9\end{array}$ & $\begin{array}{r}-15 \\
12\end{array}$ & -0.2 & -1 & \\
\hline \multirow{2}{*}{$\begin{array}{l}\text { Kernel } \\
\text { number/row }\end{array}$} & Gem. & $\begin{array}{l}-9 \\
22\end{array}$ & $\begin{array}{c}-28 \\
56\end{array}$ & $\begin{array}{l}-6 \\
21\end{array}$ & -18 & $\wedge$ & rY & \multirow[t]{2}{*}{15} \\
\hline & Sids & $\begin{array}{l}-9 \\
13\end{array}$ & $\begin{array}{c}-32 \\
30\end{array}$ & 11 & -17 & 1 & $r$ & \\
\hline \multirow{2}{*}{$\begin{array}{l}\text { Grain yield } \\
\text { (ard/fad) }\end{array}$} & Gem. & $\begin{array}{c}-18.22 \\
2.65 r\end{array}$ & $\begin{array}{c}-511 \\
93\end{array}$ & $\begin{array}{l}-6.91 \\
18.57\end{array}$ & $\begin{array}{l}-47 \\
91\end{array}$ & 9.68 & 52 & \multirow[t]{2}{*}{60} \\
\hline & Sids & $\begin{array}{r}-9.20 \\
29.68\end{array}$ & $\begin{array}{r}-57 \\
92\end{array}$ & $\begin{array}{r}-5.56 \\
24.63\end{array}$ & $\begin{array}{r}-24 \\
90\end{array}$ & 17.63 & 67 & \\
\hline
\end{tabular}

Inbreeding depression decreased when calculated from half-sib families than those from full-sib families; that was expected where the second calculation measures the reduction from a particular cross which the non additive effects could be appeared inducing extreme values.

It is noted that, there were both negative and positive values for all the studied traits at both locations referring to unexpected values were obtained; i.e., inbreeding depression did not occur in some cases, on the contrary, $S_{1}$ performance was more favorable than their opposite outbred performance.

By looking over the performance of couples of families for parents, there was no clear relation between the performance of inbred and outbred families.

Prediction of genetic gain for two different selection methods procedures (one depends on inbred progeny performance and the other one depends on outbred progeny performance) was computed by finding out genetic variance and heritability estimates across the coming sequential parameters.

\section{Mean square :}

Mean square values in Table 3 showed highly significant variation among $\mathrm{S}_{1}$ progenies and males at both locations for all the studied traits. Existence of significant variation among our germplasm showed the presence of genetic variation, providing the chance of selection for desirable alleles in population under study.

As for Females mean square, significant variation was noticed for most traits at only one location. Highly significant variation was detected among females for ear length, ear diameter and grain yield under both locations. For days to $50 \%$ silking, plant height and kernels number/row, significanct variation was detected only at Sids location, while Gemmeiza location had the significant variation for rows number/ear and ear position. However, no significant variation was found among females at both locations 
for ear height trait. It is noticed that even the significant values for females mean squares were small in amount relative to the values of males mean square which refer to the lack of differences among females that have the same parent in common. Thus, this certainly affected on estimated genetic parameters.

Comparable to each other, Gemmeiza location had the larger mean square values for $S_{1}$ than those at Sids location for all traits of interest, except for grain yield, where the values at both locations were nearly equal. The same increasing trend towards Gemmeiza location was noticed for males mean squares for all the studied traits and for females mean squares for most of the studied traits, which confirms that Gemmeiza circumstances was the higher in introducing variability among germplasm

Table 3 : Mean square and C.V.(\%) values for analysis of variance for $S_{1}$ and Design I progenies at Gemmeiza and Sids locations for all the studied traits.

\begin{tabular}{|c|c|c|c|c|c|c|}
\hline & \multicolumn{2}{|c|}{ Days to $50 \%$ silking } & \multicolumn{2}{|c|}{ Plant height } & \multicolumn{2}{|c|}{ Ear height } \\
\hline & Gem & Sids & Gem & Sids & Gem & Sids \\
\hline$S_{1}$ & ${ }^{* *} 11$ & $\Lambda^{\star *}$ & ${ }^{* *} \vee \leq 9$ & *0 017 & $r r^{* *}$ & **o. \\
\hline Error & $1, \varepsilon$ & 1,7 & 1ro & $1 \leq \varepsilon$ & 71 & $V V$ \\
\hline C.V. & 1,1 & $r, 1$ & $7, r$ & $0, \xi$ & $\Lambda, r$ & $V, \varepsilon$ \\
\hline$(\mathrm{m}) / \mathrm{S}$ & $1 \varepsilon, r^{* *}$ & ${ }^{* *} 0, \Lambda$ & $10 \wedge r^{* *}$ & ${ }^{* *} \vee 91$ & ${ }^{* *} \wedge \cdot \varepsilon$ & $\varepsilon 07^{* *}$ \\
\hline$(\mathrm{F}) / \mathrm{m} / \mathrm{S}$ & $r, r$ & $1, \mathrm{v}^{* *}$ & YYY & $1 \pi r^{* *}$ & $1 \wedge \lambda$ & 91 \\
\hline Error & $r, 1$ & 1 & YIT & $11 \leq$ & 109 & 94 \\
\hline \multirow[t]{3}{*}{ C.V. } & $r, \varepsilon$ & $1, V$ & $7, r$ & $\varepsilon, \varepsilon$ & 9,7 & $V, 1$ \\
\hline & \multicolumn{2}{|c|}{ Ear position } & \multicolumn{2}{|c|}{ Ear length } & \multicolumn{2}{|c|}{ Ear diameter } \\
\hline & Gem & Sids & Gem & Sids & Gem & Sids \\
\hline$S_{1}$ & ${ }^{* *}+4$ & $1 r^{* *}$ & ${ }^{* *} \mathrm{~V}, \mathrm{~T}$ & $7, \lambda^{* *}$ & $\cdot, \Gamma \ldots{ }^{* *}$ & $\cdot, 11 \Gamma 7^{*}$ \\
\hline Error & $\mathrm{V}, \mathrm{V}$ & 7,7 & $r, r$ & $r, r$ & $\cdot, \cdot T \leq$ & $\cdot, \cdot, 7$ \\
\hline C.V. & $\varepsilon, 9$ & $\varepsilon, V$ & $1 \cdot, \varepsilon$ & $\Lambda, \xi$ & 7,0 & $r, v$ \\
\hline$(\mathrm{m}) / \mathrm{S}$ & $\sum \Sigma^{* *}$ & $11^{* *}$ & $V, 7^{* *}$ & $0, r^{* *}$ & $\cdot, Y \vee T^{* *}$ & $\cdot, 1 \wedge V^{*}$ \\
\hline$(\mathrm{F}) / \mathrm{m} / \mathrm{S}$ & $1 V^{* *}$ & 0 & $r, r^{* *}$ & $r, 0^{* *}$ & $\cdot, 101$ & $\cdot, \cdot \pi r$ \\
\hline Error & Ir & 7 & $r, r$ & $1, r$ & $\cdot, \cdot 19$ & $\cdot, \cdot T V$ \\
\hline \multirow[t]{3}{*}{ C.V. } & 1 & $\varepsilon, 0$ & $\Lambda, V$ & $0, \wedge$ & $V, r$ & $\varepsilon, 1$ \\
\hline & \multicolumn{2}{|c|}{ Rows number/ear } & \multicolumn{2}{|c|}{ Kernel number/row } & \multicolumn{2}{|c|}{ Grain yield } \\
\hline & Gem & Sids & Gem & Sids & Gem & Sids \\
\hline$S_{1}$ & $r, 7^{* *}$ & $r, I^{* *}$ & $r \Lambda^{* *}$ & $r V^{* *}$ & $r q^{* *}$ & $\sum r^{* *}$ \\
\hline Error & 1,1 & $1, r$ & $9, \varepsilon$ & $1 T$ & $r, 4$ & $r, r$ \\
\hline C.V. & $V, 0$ & 7,9 & $1 \cdot, r$ & 1,9 & $r \cdot, \Lambda$ & $r \cdot, 0$ \\
\hline$(\mathrm{m}) / \mathrm{S}$ & $7, r^{* *}$ & $\Gamma, \Lambda^{* *}$ & $r \Lambda^{* *}$ & $r 1,1^{* *}$ & $01,1^{* *}$ & $\Gamma q, \varepsilon^{* *}$ \\
\hline$(\mathrm{F}) / \mathrm{m} / \mathrm{S}$ & $1, V^{* *}$ & $1, r$ & 1. & $1 \cdot, 7^{* *}$ & $1 \varepsilon, 9^{* *}$ & $17, \varepsilon^{* *}$ \\
\hline Error & $\cdot, 9$ & 1,1 & $9, r$ & $\wedge, \uparrow$ & $0, \varepsilon$ & 7,7 \\
\hline C.V. & $7, \varepsilon$ & $7, V$ & $\wedge$ & $v, 1$ & $T, \varepsilon$ & $9, V$ \\
\hline
\end{tabular}

Design I parameters : Obtained results in Table 4 showed that: for days to $50 \%$ silking and plant height traits, males variance exceeded with doubles 
females variance in most estimates; Gemmeiza location exhibited higher ranges. Mathematically, this is the reason of being dominance variance a negative value and this a result of being females mean squares was small relative to the values of males mean squares, it seems that there is biased estimates. However, additive variance was significant and redoubled under Gemmeiza location than under Sids location as a result of being males variances had the same trend and a cause of being genotypic and phenotypic variances had the same trend.

For ear height and ear position, Females variances were either non significant or negative values at both locations, in the same time, males variances were significant and predominant. It is easily predictable that dominance variances were negative values for both traits under both locations. However, additive variance was significant and redoubled under Gemmeiza location than under Sids location, influenced by males variance under both locations.

Table 4 : Design I parameters for different studied traits at Gemmeiza and Sids locations

\begin{tabular}{|c|c|c|c|c|c|c|}
\hline \multirow[t]{2}{*}{ Parameters } & \multicolumn{2}{|c|}{ Days to $50 \%$ silking } & \multicolumn{2}{|c|}{ Plant height } & \multicolumn{2}{|c|}{ Ear Height } \\
\hline & Gem. & Sids & Gem. & Sids & Gem. & Sids \\
\hline$\sigma^{2} m$ & $1.5^{*}$ & $0.5^{*}$ & $170^{*}$ & $79^{*}$ & $77^{*}$ & $46^{*}$ \\
\hline$\sigma^{2} f$ & 0.1 & $0.3^{*}$ & 4.4 & $24.3^{*}$ & 14.4 & 0 \\
\hline$\sigma^{2} A$ & $6^{*}$ & $2.1^{*}$ & $681^{*}$ & $318^{*}$ & $308^{*}$ & $182^{*}$ \\
\hline \multirow[t]{3}{*}{$\sigma^{2} \mathbf{D}$} & 0 & 0 & 0 & 0 & 0 & 0 \\
\hline & \multicolumn{2}{|c|}{ Ear position } & \multicolumn{2}{|c|}{ Ear length } & \multicolumn{2}{|c|}{ Ear diameter } \\
\hline & Gem. & Sids & Gem. & Sids & Gem. & Sids \\
\hline$\sigma^{2} m$ & $3.3^{*}$ & $1.6^{*}$ & $0.6^{*}$ & $0.3^{*}$ & $0.015^{*}$ & $0.016^{*}$ \\
\hline$\sigma^{2} \mathbf{f}$ & $2.8^{*}$ & 0 & $0.5^{*}$ & $0.6^{*}$ & $0.035^{*}$ & $0.013^{*}$ \\
\hline$\sigma^{2} \mathbf{A}$ & $13^{*}$ & $6^{*}$ & $2.2^{*}$ & $1.4^{*}$ & $0.059^{*}$ & $0.062^{*}$ \\
\hline \multirow[t]{3}{*}{$\sigma^{2} D$} & 0 & 0 & 0 & 1 & 0.081 & 0 \\
\hline & \multicolumn{2}{|c|}{ Rows number/ear } & \multicolumn{2}{|c|}{ Kernels number/row } & \multicolumn{2}{|c|}{ Grain yield } \\
\hline & Gem. & Sids & Gem. & Sids & Gem. & Sids \\
\hline$\sigma^{2} m$ & $0.6^{*}$ & $0.3^{*}$ & $2.2^{*}$ & $1.3^{*}$ & $4.5^{*}$ & $2.9^{*}$ \\
\hline$\sigma^{2} \mathbf{f}$ & $0.4^{*}$ & 0.1 & 0.5 & 1.0 & $4.7^{*}$ & $4.9^{*}$ \\
\hline$\sigma^{2} A$ & $2.3^{*}$ & $1.3^{*}$ & $8.9^{*}$ & $5.3^{*}$ & $18.1^{*}$ & $11.5^{*}$ \\
\hline$\sigma^{2} D$ & 0 & 0 & 0 & 0 & 0.8 & 8.0 \\
\hline
\end{tabular}

* 0 refers to negative value

For ear length and ear diameter, all estimates of DI parameters were significant, except dominance variance at both locations. It can be seen that dominance variance was exceptionally larger than additive variance in ear diameter trait at Gemmeiza location. Also, under the same location, additive variance was nearly twice its counterpart under Sids location for ear length, while nearly there was no difference between additive variance values at both locations for ear diameter.

For rows number/ear and ear kernels number/row, the significance was for males and additive variances at both locations for both traits and for 
females variance at Gemmeiza location for rows number/ear. Gemmeiza location had the higher values of DI parameters, except dominance variance which was a negative value at both locations.

For grain yield, all DI parameters were significant, except dominance variance at both locations. It can be noticed that dominance variance multiplied at Sids location, however additive variance was larger at Gemmeiza location. May be Gemmeiza location circumstances represented a stress on genetic materials comparing to those at Sids location. These circumstances may provided an opportunity for differences in performance of germplasm affecting more on males variance and, consequently increasing additive genetic variance and decreasing dominant genetic variance than of those at Sids location.

As it turned out, there is an obvious phenomenon in our estimates of dominance variance computed from Design I represented in the negative values. These results was in agreement with those reported by Nawar (1985), El-Hosary (1986), El-Hosary (1987) and El-Absawy (1990). These negative values were as a result of being females variance less than males variance in most studied traits, indicating that the magnitude of differences inside male groups were small. May be genetic sample was not representative to the population because occurrence of assortative mating between males and their respective females. Relating to this, Brigitt and Gallais (1992) studied the effect of assortative mating on male and female variances in a nested mating design. They found that under positive assortative mating, additive variance is systematically over estimated and dominance variance is under estimated; also it was mentioned before by Lindsey et al (1962) that the nonrandomness of pollination would result in crossing the early male parents to the early female parents and the late males to the late females which led to reduce the variability among females which in turn affects on dominance estimates and it might be negative values. They suggested delaying planting of a portion of population from which the males are chosen to reduce assortative mating of males with females. Early flowering female silks can be held for later pollination by covering the ear shoot to prevent fertilization. Randomly chosen males from the delaying planting can be crossed with the females without regard to vigor, plant size, maturity, etc. May be epstasis also played a role in being biased estimates, whereas manifesting of both positive and negative values of inbreeding depression for all studied traits in Table (2) is a clue to probability of epastasis existence. In connection with this, Wright (1922) studied hybrid vigor and inbreeding depression and stated that, if the change of performance is proportional to the change of heterozygosity, epstatsis is either negligible or nondetectable and implies that the change is depend on some level of dominance. For sure, there is upward bias due to genotype-environment interaction which was evident in grain yield, whereas there was an obvious difference in estimates between the two locations. The upward bias for genetic variance components is resulting from not avoiding genotype-environment interaction from calculations, and it is obvious that the bigger beneficiary among genetic variance components in our results was the additive genetic variance. However, our results showed the predominance of additive genetic variance in all the studied traits. 
Phenotypic variance components: Results in Table 5 provides information about phenotypic variance $\left(\sigma^{2} \mathrm{Ph}\right)$ with its two components (genotypic variance $\left(\sigma^{2} G\right)$ and environmental variance $\left(\sigma^{2} E\right)$ for $S_{1}$ and Design I progenies at Gemmeiza and Sids locations for all the studied traits.

Genetic variance estimated either for Design I or $S_{1}$ progenies was significant and increased largely from Sids location to Gemmeiza location in days to $50 \%$ silking, plant height, ear height, ear position, rows number/ear, kernels number/row and ear diameter traits, while for ear length and grain yield genetic variance was nearly similar for both locations.

Table 5 : Phenotypic, genotypic and environmental variances for $S_{1}$ and Design I progenies at Gemmeiza and Sids locations for all the studied traits.

\begin{tabular}{|c|c|c|c|c|c|}
\hline \multirow[t]{2}{*}{ Traits } & \multirow[t]{2}{*}{ Param. } & \multicolumn{2}{|c|}{$\mathrm{S}_{1}$ proginies } & \multicolumn{2}{|c|}{ Design I progenies } \\
\hline & & Gem. & Sids & Gem. & Sids \\
\hline \multirow{3}{*}{$\begin{array}{l}\text { Days to } 50 \\
\text { silking }\end{array}$} & $\sigma^{2} G$ & $5.6^{*}$ & $3.2^{*}$ & $6^{*}$ & $2.1^{*}$ \\
\hline & $\sigma^{2} E$ & 0.9 & 0.8 & 1.0 & 0.5 \\
\hline & $\bar{\sigma}^{2} \mathbf{P h}$ & 6.5 & 4 & 7.0 & 2.6 \\
\hline \multirow{3}{*}{ Plant height } & $\sigma^{2} \mathbf{G}$ & $312^{*}$ & $186^{*}$ & $681^{*}$ & $318^{*}$ \\
\hline & $\sigma^{2} E$ & 63 & 72 & 106 & 57 \\
\hline & $\sigma^{2} \mathbf{P h}$ & 375 & 258 & 787 & 375 \\
\hline \multirow{3}{*}{ Ear Height } & $\sigma^{2} \mathbf{G}$ & $127^{*}$ & $87^{*}$ & $308^{*}$ & $182^{*}$ \\
\hline & $\sigma^{2} E$ & 34 & 39 & 80 & 46 \\
\hline & $\sigma^{2} \mathbf{P h}$ & 161 & 126 & 388 & 228 \\
\hline \multirow{3}{*}{ Ear position } & $\sigma^{2} \mathbf{G}$ & $14.15^{*}$ & $2.7^{*}$ & $13^{*}$ & $6^{*}$ \\
\hline & $\sigma^{2} E$ & 3.85 & 3.3 & 6 & 3 \\
\hline & $\sigma^{2} \mathbf{P h}$ & 18 & 6 & 19 & 9 \\
\hline \multirow{3}{*}{ Ear length } & $\sigma^{2} \mathbf{G}$ & $2.65^{*}$ & $2.25^{*}$ & $2.2^{*}$ & $2.4^{*}$ \\
\hline & $\sigma^{2} E$ & 1.15 & 1.15 & 1.1 & 0.6 \\
\hline & $\sigma^{2} \mathbf{P h}$ & 3.8 & 3.4 & 3.3 & 3 \\
\hline
\end{tabular}

\begin{tabular}{|c|c|c|c|c|c|}
\hline \multirow{3}{*}{ Ear diameter } & $\sigma^{2} \mathbf{G}$ & $0.118^{*}$ & $0.055^{*}$ & $0.140^{*}$ & $0.062^{*}$ \\
\hline & $\sigma^{2} E$ & 0.032 & 0.013 & 0.044 & 0.018 \\
\hline & $\sigma^{2} \mathrm{Ph}$ & 0.15 & 0.068 & 0.184 & 0.08 \\
\hline \multirow{3}{*}{$\begin{array}{l}\text { Rows } \\
\text { number/ear }\end{array}$} & $\sigma^{2} \mathbf{G}$ & $1.25^{*}$ & $0.45^{*}$ & $2.3^{*}$ & $1.3^{*}$ \\
\hline & $\sigma^{2} \mathbf{E}$ & 0.55 & 0.6 & 0.5 & 0.5 \\
\hline & $\sigma^{2} \mathbf{P h}$ & 1.8 & 1.05 & 2.7 & 1.8 \\
\hline \multirow{3}{*}{$\begin{array}{l}\text { Kernels number } \\
\text { /row }\end{array}$} & $\sigma^{2} \mathbf{G}$ & $14.3^{*}$ & $6.95^{*}$ & $8.9^{*}$ & $5.3^{*}$ \\
\hline & $\sigma^{2} E$ & 4.7 & 6.3 & 4.6 & 4.3 \\
\hline & $\sigma^{2} P h$ & 19 & 13.25 & 13.5 & 9.6 \\
\hline \multirow{3}{*}{ Grain yield } & $\sigma^{2} \mathbf{G}$ & $17.7^{*}$ & $19.4^{*}$ & $18.9^{*}$ & $19.5^{*}$ \\
\hline & $\sigma^{2} E$ & 1.8 & 1.6 & 2.7 & 3.3 \\
\hline & $\sigma^{2} \mathbf{P h}$ & 19.5 & 21 & 21.6 & 22.8 \\
\hline
\end{tabular}

Relative to both progenies, we found doubling trend in favor of Design I for plant height, however both proginies took turns in excesses at both locations for days to $50 \%$ silking. Design I had the larger values for ear height at both locations and for ear position at Sids location.. For rows number/ear, values of Design I were almost twice $S_{1}$ values, however for kernels number/row, $S_{1}$ genetic variance surpassed with small difference at Sids location and large differences at Gemmeiza location. Regarding ear 
length ear diameter and grain yield, values apparently was equal for both progenies.

It is known that increase of genetic variance relative to phenotypic variance led to more feasibility of the selection process by enlarge for the proportion of the differences among selection units that due to genotypes and not to the environment.

Environmental variance acted as a follower to the previous estimate of error mean square, where it was larger at Gemmeiza location for most studied traits for either $S_{1}$ or Design I progenies; double values between both locations were recorded for days to $50 \%$ silking, plant height, ear height, ear position, ear diameter and ear length traits in case of Design I and for ear diameter in case of $S_{1}$ progenies. This does not necessarily mean that the environmental impact was higher at location with higher value of environmental variance, where it is a matter of relative related by environmental effect to additive genetic effect which reflected indirectly by estimating heritability as we will see in the coming point.

Since, phenotypic variance consisted of sum of genetic variance and environmental variances, it took the aggregate trend of increment between the two locations and both progenies.

Influence of environments was obvious on genetic variance in our data, where it was larger at Gemmeiza than at Sids location in most studied traits. It was evident that Gemmeiza location had less favorable circumstances than Sids location; this was deduced from values of mean performance at both locations in Table 1. May be this circumstances provided the opportunity for more variation under this location for most studied traits as a result of different responses by genetic material towards these circumstances.

In most studied traits, Design I progenies had the larger genetic variance as contrasted with $S_{1}$ progenies, these findings were in agreement with those reported by Nawar (1986). May be this superiority of Design I is due to constricting variability among $S_{1}$ families by existence of a majority of $S_{1}$ families with plenty of harmful alleles in corresponding to rarity of $S_{1}$ families with few harmful alleles; this was noted by optical vision in field, and from mean performance tables. It could be the majority of exotic sources composed in our population beyond poor performance of most $S_{1}$ families and consequently less variation among them.

Heritability and Expected genetic gain :

Heritability values for both $S_{1}$ and Design I progenies shown in Table 6 exhibited a rise in estimates for all traits; it was not surprising according to our results where in most cases genetic variance estimated for Design I progenies and in all cases for $S_{1}$ progenies was entirely due to additive genetic variance.

Regarding comparing the two locations: they differed with small difference for days to $50 \%$ silking and plant height in both selection methods. For ear height and ear position, estimates varied with small differences in case of design I, while the differences were noticeable for $S_{1}$ families in favor of Gemmeiza location. For ear length and ear diameter, the two locations did not exhibit a large difference in case of $S_{1}$, while for Design I, values 
decreased frequently from Gemmeiza to Sids location for ear length, and vice versa for ear diameter; that is due to the noticeable values of dominance variance which differed than zero under locations with low heritability, which led to increasing in the phenotypic variance causing these reductions.

Table 6: Heritability and Expected genetic gain estimates for $S_{1}$ and Design I progenies at Gemmeiza and Sids locations for all the studied traits.

\begin{tabular}{|c|c|c|c|c|c|c|c|c|}
\hline \multirow{3}{*}{ Traits } & \multicolumn{4}{|c|}{ Hertability } & \multicolumn{4}{|c|}{ Expected genetic gain } \\
\hline & \multicolumn{2}{|c|}{$\mathrm{S}_{1}$ progenies } & \multicolumn{2}{|c|}{ Dl progenies } & \multicolumn{2}{|c|}{$\mathrm{S}_{1}$ progenies } & \multicolumn{2}{|c|}{ Dl progenies } \\
\hline & Gem. & Sids & Gem. & Sids & Gem. & Sids & Gem. & Sids \\
\hline Days to $50 \%$ silking & 86 & 80 & 85 & 81 & 4 & 3 & 4 & 2 \\
\hline Plant height & 83 & 72 & 86 & 85 & 28 & 20 & 43 & 29 \\
\hline Ear height & 79 & 69 & 79 & 80 & 18 & 14 & 28 & 21 \\
\hline Ear position & 79 & 45 & 70 & 68 & 5.9 & 1.9 & 5.3 & 3.7 \\
\hline Ear length & 70 & 66 & 66 & 45 & 2.4 & 2.2 & 2.1 & 1.4 \\
\hline Ear diameter & 79 & 81 & 32 & 77 & 0.5 & 0.4 & 0.2 & 0.4 \\
\hline Rows number/ear & 69 & 43 & 83 & 71 & 1.6 & 0.8 & 2.4 & 1.7 \\
\hline Kernels number/row & 75 & 52 & 66 & 55 & 8 & 3 & 4 & 3 \\
\hline Grain yield & 91 & 92 & 83 & 50 & 7.06 & 7.45 & 6.87 & 4.24 \\
\hline
\end{tabular}

For rows number/ear and kernels number/row, estimates for both progenies exhibited reasonable differences in favor of Gemmeiza location because genetic variances were larger at this location. However, for grain yield, heritability did not differ at both locations for $S_{1}$ families, whereas differed for Design I and Sids location gave the lowest value as a consequence of obtaining larger dominance variance at this location circumstances.

In general, heritability estimates in our results were larger than most previous estimates of Design I; of course this is due to larger portion of additive genetic variance in our results, which also amounted between the values of both methods resulting in there was no trend for heritability increases between the two selection methods over all the studied traits; i.e., estimates were higher on the side of $S_{1}$ family selection for ear diameter, ear length and grain yield, while for some traits (plant height, ear height, rows number/ear) were in favor of half-sib family selection; increments contrasted between the two locations in some other traits (ear position, kernels number/row); estimates were nearly equal in both methods for days to $50 \%$ silking.

Genetic gain calculated for both selection methods was bigger at Gemmeiza location for traits of days to $50 \%$ silking, plant height, ear height, ear position, rows number/ear and kernels number/row reflecting the higher magnitude of heritability and phenotypic variance at this location. For ear length and ear diameter, genetic gain showed nearly no differences between the two locations in case of $S_{1}$, whereas for Design I, when the differences in heritability values expanded, the differences in genetic gain followed them. While, for grain yield, values approximately did not differ from location to another for $S_{1}$ family selection, and increased from Sids location to Gemmeiza location for half-sib family selection. 
Most previous studies comparing genetic gain among different selection methods stated with the priority of $S_{1}$ family selection because of the bigness magnitude of additive genetic variance estimated from this method. It is not surprising as affected by heritability estimates in both selection methods that expectation of our results were conflicting among

different studied traits: the preference was for $S_{1}$ family selection for studied yield components (ear diameter, ear length \& kernels number/ear), except rows number/ ear where the advantage was for half-sib family selection plus to plant height, ear height and ear position traits. Both methods were almost equal for $50 \%$ silking. And still $S_{1}$ family selection has the bigger expected gain for grain yield trait.

Generally, prediction was encouraging for completing the first cycle of recurrent selection for yield improvement of the population under selection.

\section{REFERENCES}

Brigitt, E. F. and A. N. Gallais (1992). Genetic variance components estimation in a nested design with positive assortative mating and application to maize. Crop Sci., 32: 1127-1130.

Cochran, W. G. and G. N. Cox (1957). Experimental Design. (ed.) Jihn Wiley and Sons, Inc, New York, U. S. A.

Comstock, R. E. and H. F. Robinson (1948). The components of genetic variance in populations of biparental progenies and their use in estimating the degree of dominance. Biometrics 4: 245-266.

EL-Absawy, E. A. A. (1990). Comparison between some experimental genetic designs in two populations of maize. Ph.D. Thesis, Zagazig Univ., Egypt.

El-Hosary, A. A. (1986). Estimation of genetic variance in open pollinated variety with reference to expected gain from selection. Egyptian $\mathrm{J}$. Agron., 11: 119-128.

El-Hosary, A. A. (1987). Genetic studies in a synthetic variety of maize. Egypt. J. Agron., 12: 57-64.

Empig, L. T.; C. O. Gardener and W. A. Compton (1972). Theoretical gains for different population improvement procedures. Nebraska. Agric. Exp. Staion. Pub. 26: $1-22$.

Falconer, D. S. (1960). Introduction to Quantitative Genetics. (ed.) The Ronald Press Co., New York, U.S.A.

Gamea, H. E. (2010). Genetic improvement in yield and oil percentage in maize. Ph. D. Thesis, Menufiya Univ., Egypt.

Hallauer, A. R. and J. B. Miranda (1981). Quantitive Genetics in Maize Breeding. lowa State University press, Ames. First Edition.

Lindsey, M. F.; J. H. Lonnquist and C. O. Gardner (1962). Estimates of genetic variance in open-pollinated varieties of corn Belt corn. Crop Sci., 2: 105-108. 
Nawar, A. A. (1985). Estimation of genetic parameters in a synthetic variety of maize (Zea mays, L.) under two nitrogen levels. Communications in Sci. \& Dev. Res., 11: 228-239.

Nawar, A. A. (1986). Comparative studies between two mating designs for estimating the genetic variance components in maize (Zea mays, L.). Communications in Sci. \& Dev. Res., 13: 96-107.

Wright, S. (1922). The effect of inbreeding and crossbreeding on guinea pigs. III. Crosses between highly inbred families. USDA Bull. 1121.

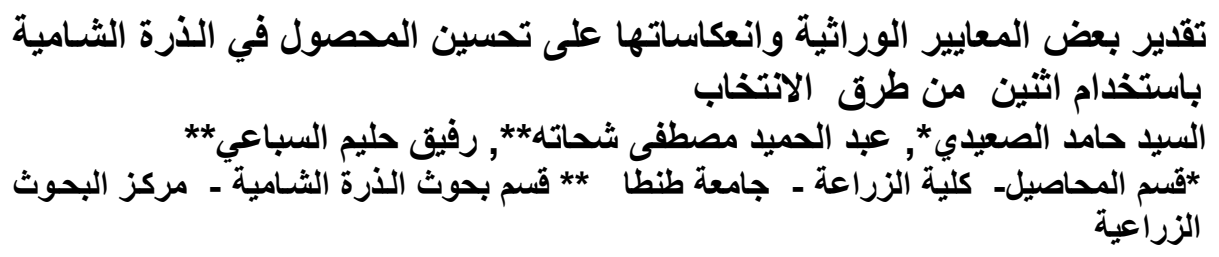

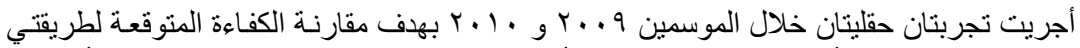

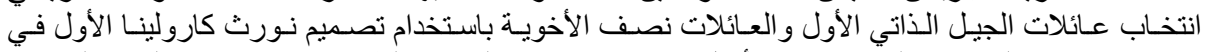

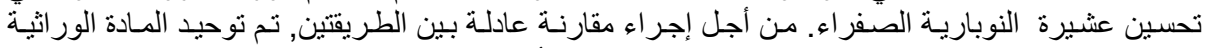

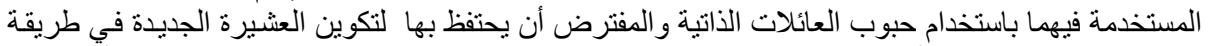

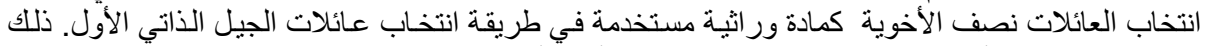

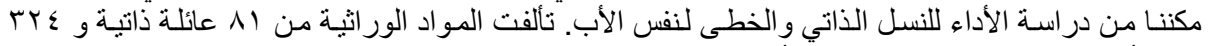

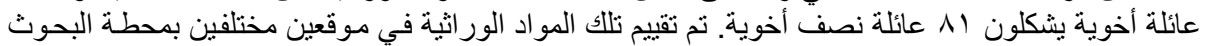

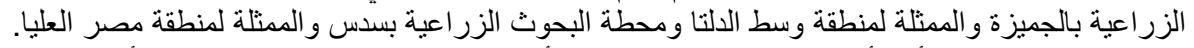

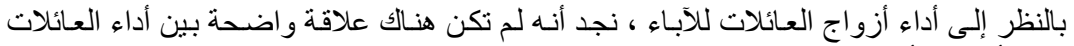

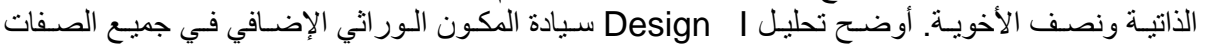

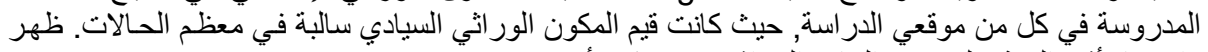

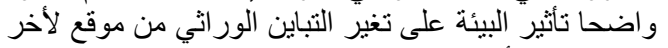

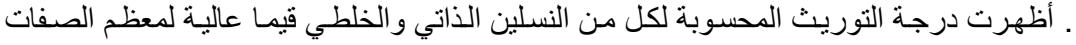

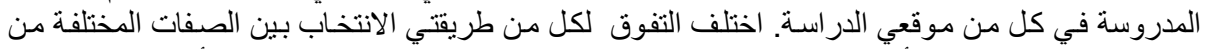

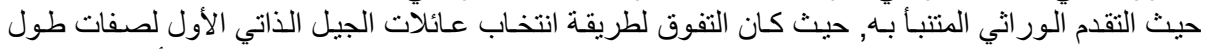

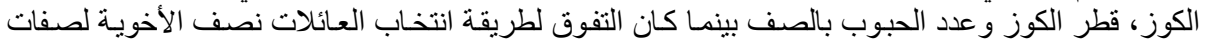

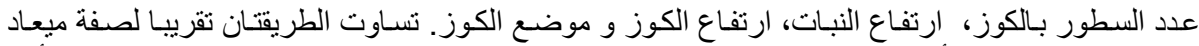

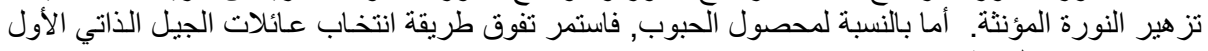
في تحسين هذه الصفة. وقد خلصت هذه الدراسة إلى جدوى إتمام الحلقة الاتنخابية للعشبرة محل الدراسة

كلية الزراعة - جامعة المنصورة كلية الزراعة - جامعة المنوفيه
قام بتحكيم البحث

أ.بد / احمد ابو النجا قنديل

أ.د / أد / عبد الحميد احمد نوار الجنايل 